\title{
EFFECT OF APPLICATION OF NPK AND BORON ON YIELD ATTRIBUTES OF MAIZE (ZEA MAYS L.) AND OTHER CROPS AND INFLUENCE OF SOIL PROPERTIES: A REVIEW
}

\section{L BUBARAI \& T. THOMAS}

Department of Soil Science and Agricultural Chemistry Samhigginbottom University of Agriculture, Allahabad, India

ABSTRACT
Nitrogen, phosphorus and potassium plays a significant role on yield of crops, Boron being a micro nutrient
also plays a significant impact on crop yield, the paper review the work conducted on NPK and Boron on Maize and other
crops like Rice, chilli and wheat among others. Soil properties affecting the performance of the nutrients were also
reviewed. Most of the work cited reported a significant influence of nutrients application.
KEYWORDS: NPK, Boron \& Maize

Received: Oct 20, 2017; Accepted: Nov 11, 2017; Published: Nov 21, 2017; Paper Id.: IJASRDEC201741

\section{INTRODUCTION}

Nitrogen, phosphorous and potassium are among the essential nutrients elements which are necessary for growth and development of plant without which crops show some deficiency symptoms. Boron on the other hand is a micro nutrients which is needed by plant in tracer amount, although boron is needed in small quantities yet it's absent in plant generally shows some deficiency symptom. A lot of research work has been done on these elements and the role the play in contributing to the growth and development of crop. An attempt is made here to gather some important literature on the role boron and NPK perform in enhancing growth of plant and the role soil properties contribute in enhancing their availability to crops.

\section{Effect of NPK and Boron on Maize}

Sezer (2012), notice an increased in productivity of silage maize genotype and dry matter content, he also reported increased in plant $\mathrm{P}, \mathrm{K}$ and $\mathrm{B}$ content with boron application, at the rate of 0,48 and $200 \mathrm{~g} \mathrm{da}^{-1}$. Shargholi et al.,(2013) reported that, increased intake of nitrogen improves biological yield of corn and average dry matter yield at the rate of $1.345,1.431$ and $1.499 \mathrm{~kg}$ per square meter respectively. Also the application of boron at the rate of 1.259 to 1.383 and $1.406 \mathrm{~B} \mathrm{~kg}$ per square meter produce a positive and significant result on dry matter production. Muhammad et al.,(2012) observed that, application of boron at the rate of $0.30 \mathrm{~kg} \mathrm{ha}^{-1}$ significantly increased plant height, leaf area, stem diameter, cob weight, number of grain per cob, protein and oil content of maize. Salem et al., (2016), while studying the effect of colemenite ore as boron fertilizer on maize reported that, height of plant, stem width /grith, green and dry leaves per plant, ear head length and grain yield per pot were significantly affected with the application of $3 \mathrm{~kg}$ B. Aden et al.,(2011) suggested the addition of $7.7 \mathrm{~kg} \mathrm{ha}^{-1}$

of boron to elevate the deficiency levels of soil B. They conclude by saying that the application of the suggested boron in soil increase levels of $\mathrm{N} \mathrm{Ca}, \mathrm{Mg}, \mathrm{P}, \mathrm{K}$ and $\mathrm{Mn}$ in shoot and leaves tissues of maize, but 
decrease $\mathrm{Fe}, \mathrm{Zn}$ and $\mathrm{Cu}$ content. Palta and Karadavut (2011) reported that, the application of $3.0 \mathrm{~kg} \mathrm{Bha}^{-1}$ produce a better growth when compared to control. Mauhammad et al.,(2015) reported that, application of graded boron to maize increase all the agronomic growth parameters of maize. The increase was achieved with the application of $8 \mathrm{~kg}$ boron (granubor). Gazala et al.,(2016) observed that the application of boron at different rates in different crops have shown a positive influence on yield and other agronomical attributes in different crops thereby proving the vital role boron plays in improving yield of different crops. Umeri et al.,(2016), observed an increase in maize plant height and number of leaves, with the application of $40 \mathrm{~kg} \mathrm{~N}$ and $40 \mathrm{~kg}$ P/ha, respectively. Kolawole et al.,(2009) investigated the performance of maize, under NPK application and concluded by saying that, application of NPK fertilizer significantly increased plant height, stem girth, number of leaves, leaf area, leaf area index, dry matter accumulation and yield. Gurpreet and Kelly (2015) in their trial observed that foliar application of Boron on corn resulted in higher yield and ear leaf tissue in addition to decreasing severity of gray leaf spot; however, it increases the severity of northern leaf blight. Researchers (2014) disovered that, boron play a significant role in corn reproduction and development, they discovered that deficiency affect tasseling and kernels. Wasonga et al., (2008) observed that, maize variety tested on different soil types responded significantly, to application of phosphorous. Chatterjee et al., (1990) reported that, there is a significant correlation between boron and phosphorous on growth of maize crop. Aydan and Sevin (2006) wrote that, boron and zinc significantly increases the concentrations of phosphorous and potassium in maize, they went further to say that, boron application also increases the concentration of iron in maize crop. Similarly, many researchers have reported the significant response of maize to NPK fertilizer application ( Amanullah et al.,2014 ,Onasanya et al.,2009, and Kogbe and Adediran(2003).

\section{Others Crops}

Islam et al.,(2008) reported that, Rice and Chilli responded significantly to application of NPK fertilizers, According to the investigation, maximum doses of the fertilizer produce the best result. Laghan et al.,(2016) reported that, application of NPK and Boron on Wheat produce a promising result. The outcome of an experiment conducted by Nafiu $e t$ al.,(2011) reveal that application of NPK influence dry matter production and yield increase in egg plant.. Thambakazi $e t$ al.(2015) observed that application of NPK, to okro produce a profound increased in all the growth parameters of the plant. Base on the outcome of their research Muzzamil et al.,(2009) reported that, application of NPK and micronutrients enhance the growth parameters of sunflower. Mahmood et al.,(2006) found out that, application of different levels of nitrogen and foliar spray of boron improved the yield of faba bean. An experiment conducted by Maria and Ladislav (2014) reveal that, application of boron significantly improved the oil content in seeds of oil seed rape ( Brassica napus L.). In an experiment performed by Rajeev and Dinash (2014), they discovered that, boron has a positive influence on green. While, evaluating the effect of boron and nitrogen on broccoli Khama (2015) obtained a positive effect on the result. Similarly Manoj et al.,(2015) also observed that, application of NPK and boron yielded a significant impact on Brocolli. Jyosna and Usha (2008) observed a significant influence of boron nutrition on tomato. In summarizing the outcome of their research Rezaul et al.,(2013) noted that, combination of boron phosphorous and calcium has a positive influence on groundnut. Bao et al., ( 2015) investigated the combination of Nitrogen Boron and Sulphur on canola and came out with the result that, application of fertilizer has the potentials of improving both yield and quality of canola. In another trial by Nacer et ai.,(2013) they described that, boron nutrition influence the composition of soya bean seed. Hellal et al .(2009) in their research on sugar beet noted that, boron and nitrogen interact positively to increased yield and nutrient distribution, significantly. Soad et al., (2012) discovered that, boron has significant role in increasing growth parameters of barley, they reported that, increasing the concentration to the maximum threshold inhibit growth. Musa et al.,(2017) reported a 
significant uptake of NPK fertilizer, by groundnut variety. In another trial by Patil et al.,(2015) on millet crop, they observed a positive effect of NPK on the crop. Also, Ram et al., (2011) observed that, NPK has an influence on SP Tori ( Brassica sp) var P. T. 303. Rafique et al.,(2015), describe the combination of boron, zinc and NPK application on growth and yield traits of sunflower as significant.

\section{Factors Affecting Availability of nutrients}

Various factors affect the availability of nutrients in soils. Boron availability is influenced by soil texture, soil reaction and liming, organic matter, interaction with other elements and environmental conditions, (Dilip, 2000). Nitrogen is affected by many factors some physical and chemical while others are biochemical ( Dilip, 2015). Phosphorus in soil is affected by soil mineral, soil reaction, cation and anion concentration and soil organic matter (John et al., 2016). According to Bradey and Weil (1999) four soil conditions affect Potassium in soil, they are soil colloids, wetting and drying, freezing and thawing and the presence of excess lime.

\section{CONCLUSIONS}

Most of the work cited in this work reported a significant performance of the fertilizers on crop. There is the need therefore to create awareness to the ordinary end user that is the farmer to cultivate the habit of combining the application of both macro and micronutrients on his field so as to obtained maximum yield on his farm.

\section{REFERENCES}

1. Amanulla,K., Muhammad,. K.,Azam,K.,Imran,K.,Zahir,S., and Zahid. S.(2014) Growth and yield response of maize (zea mays L.) to foliar NPK fertilizer under moisture stress condition. Soil Environments. J. 33(2):116-123

2. Ayden.A.,. and Sevin.A. (2006) The effect of boron application on the growth and nutrients contents of maize in zinc deficient soil.Bulgarian Journal of Agric Science 12:387-392

3. Adem.G.N., Zametin..A.,Asliham.E., Oguzhan.U., Sinan.A., andMetin.T.(2011) Yield and chemical composition of corn (Zea mays $L$.) as affected by boron management.International journal of of plant, animal and environmenta[ Science vol 1 (1) $: 42-51$

4. Bao .L.M., Dilip.K.B.,Aruna.W.H., Joan.K.W.Qian ying.R.S., Claude.C., and Donald.L.S (2015) Growth Yield and Yield component of canola as affected by Nitrogen, Sulphur $\quad$ and Boron application.J.Plant Nutir.Soil Sc. 78, 658-670

5. Chatterjee.C. Sinha.P., ang Agarwala.S.G. (1990) Interactive effect of boron and phosphorous on growth and metabolism of maize grown in refined sand. Can.J.Plant.Scio.70:435-460

6. Gazala.N.,Upinder.S., and Pardeep.K. (2016) Boron-Its important in crop production,Status in Indian Soils and Crop Responses to its application.International journal of advancd Research Vol 4 Issue 5, 654-660

7. Gurpreet.K., and Kelly.A..N., (2015) Effect of foliar Boron Fertilzation of Fine Textured Soils on Corn Yields. Agronomy 5, 118

8. Hellal.F.H.,Taalab.A.S., and Safala.A.M.,(2009) Influence of nitrogen and boron nutrition in nutrient balance and sugar beat yield grown in calcareous soil,Zean Journal of applied Sciences 2 (1) 1943-2419

9. Islam.M.S., Howladan.M.L.,Rafiquzzaman.S., Bashar.H.M. and Al-manan.H.M (2008) Yield respond of Chilli and T.Aman Rice to NPK Fertilizer in Ganges Tidal Flood Plain Journal of Soil Nature 2(1) 07-13 
10. Jyolsna.V.K. and Usha.M.(2008) Boron nutrition of tomato (Lycopersicon esculentum L.) grown in the laterite soil of southern kerala. Journal of tropical Agric 46(1-2) 73-75

11. Khama..A. (2015) Effect of Nitrogen and Boron in seed Yield and Yield attributes characters of broccoli. Inter J.Appl.Sci.Biotechnol..Vol 3(3): 541-544

12. Kolawole.E., Law.O., and Joyce .F., (2009) The Performance of Zea mays as Influence by NPK Fertilizer Application. Notulae Scientia Biologicae 1 (1), 59-62

13. Kogbe,A.H., and Adediran,J.H (2003) Influence of nitrogen, phosphorous and potassium application on the yield of maize in the savanna zone of Nigeria.African Journal of Biotechnology vol 12 (10): pp345-391

14. Laghan.A.H.,Laghari.G.M.,Anasni.M.A.,Mirgati.M.A.,Laghari.U.A.,Lehan.S.J.,Lagahan.A.B and Abbasi. Z.A. (2016) Effect ofNPK and Boron on Growth and Yield of of Wheat Variety T.l 83 at Tandojan Soil. Advances in Environmental Biology 10 (10) $p, 209-216$

15. Maria.V. and Ladislav.D,(2014) Effect of increasing doses of boron on oil production on oilseed rape (Brassica napus L.) Rerieved from Mendel. Net

16. Manoj.K.S.,Trilok.C.,Mukesh.K.,Singh.K.V.,Lodhi.S.K.,Singh.V.P.,Vikiant.S.S.(2015) Response of different doses of NPK and Boron on Growth and Yield of Broccoli (Brassica oleracea L.Var Italica) International Journal of Bio.resource and stress $6(1): 108-120$

17. Mahmood.M.S., Abdalla, F,E..Abour-El Noor.E.A., Mottaleb.A,. and El-Saady.A.M., (2006) Boron/Nitrogen interaction Effect on Growth and Yield of faba bean plant grown undersandy Soil condition.Ineternational Journal of Agric Research 1(4): $322-330$

18. Muhammad.S.H., Subbarayappa.C.T., and Sarala.K.J.(2015) Effect of graded levels of boron on growth and yield attributes of Maize in calcareous a Soils. Trends in bioscience 8(13), 3291- 3296

19. Muzzamil .,H.S., Fateh.C.O., Kaleem. F.M., and Gandahi. W. (2009)Effect of NPK micronutrients and placement on the Growth and Yield of Sunflower Sahard J Of Agric Vol 25.No1

20. Musa,A.M.,Singh.L.,Tame.V.T., and Bubarai.M.L.(2017) Nitrogen, Phosphorus and Potassium uptake by some varieties of groundnut (Arachis hypogeal L.) as influenced by phosphorus application in Yola and Mubi Adamawa state. Journal of Agriculture and Vet Sc pp 40-45

21. Nafiu.A.K., Togu.A.O.,Abiodun.M.O., and Chude..V.O (2011) Effect of NPK Fertilizer on Growth dry matter production and yield of egg plantin south western Nigeria.Agriculture and Biology Journal of N.America 2(7). 1117-1126

22. Nacer.B.,Yanbor.H.,Alemu.M.,My.A.K.,and Craig.A.B.(2013) Effect of foliar Boron application on seed composition cell boron and $\partial^{15} \mathrm{~N}$ and $\partial{ }^{13} \mathrm{C}$ Isotopes in water stress soya bean plant. Frontiers in plant Sc. Vol 4. $270=271$

23. Nuhammad.T., Asghar.A., Farkhan.K.,Muhammad.N.,Naeem.F., and Muhammad.W, (2012) Effect of foliar Applied Boron Application on Growth, Yield and Quqlity of Maize (Zea mays L.) PK Journal Sci ind res. Ser.B:bio.sci 55(3) 117-121

24. Researchers (2014) Researchers Find boron facilitates stem cell growth and development in corn (2014 August $\left.25^{\text {th }}\right)$ retrieved 14 January 2017 from htpp://phys.org/news/2014-08 boron stem cell-growth.corn.htm.

25. Rafique,A.B.,Sana,U.B,.Shabaz,K.B.,Allahbakh.B.,Hafez.N.B.,Wassaem.B.,Shahabbuudin., Zahid,S., Musslim, B., Waseem, A., Shabeen. A., Muzaffar,A., and Shakon,A.,(2015)Effect of zinc and boron in combination with NPK on Sunflower (Helianthus annul L.) growth and yield.Journal of Biology Agric and Health care. Vol(50): 2224-3208 
26. Onasanya, A.,Oikeh,S.,Nwilene,F.,Oyelekan,O (2009) Growth response of Maize (zea mays) to different rates of Nitrogen and Phosphorous fertilizers in southern Nigeria. World Journal of Agricultureral Sciences 5(4): 400-407

27. Palta. C., and Karadavit. U. (2011) Shoot growth curve analysis of maize culitiver under boron deficiency. The Journal of animal and Plant Sciences 2(4): 696 - 699

28. Patil,S.V.,Bhosale,A.S., and Khambal,P.D. (2015)Effect of various levels of fertilizer on growth and yield of finger millet. Journal of Agric and Vet. Science. Pp 49-52

29. Rajeev. P., and Dinesh.K.(2014) Influence of Soil and foliar applied Boron on green Gram.in calcareous Soils International Journal of Agric Envt and Biotech 7(1) 129-136

30. Ram,B.,Suni,C., Tarence,T., Dharambir. D.(2011) Effect of different levels of phosphorus and sulphur on yield availability of NPK, Protein and oil content in Torik (Brassica sp) var PT 33.Journal of Agriculture and Bilogical Sciences. Vol 6 (2): 1990 6145

31. Rezaul.K..Sabina.Y.,Mominu.T.K, and Abdurrahman.S.,(2013) Effect of Phosphorous, Calcium and boron on Growth and yield of groundnut (Arachis hypogeal,L.) International Journal of Bio-Sc and Bio Tech vol.5 No 3 51-60

32. Shagoli.S., Nemati.N. and Silspur .M. (2013) Effect of nitrogen fertilizer and spray the element boron some agronomic traits of corn (Zea mays L.) hybrid (9SC704) in varamin, Iran, Annals of Biological Research, 4 (3): 37-40

33. Saleem.M., Gulaba.K,. Gandahi.W. Bhattis. S.M and Velo.S. (2016) Effeicacy of colemmenite ore as boron fertilizer for maize (Zea mays L.) growth and yield.Sci Int (Lahore) 28(3), 3071-3074

34. Sezer.S.(2012) Effect of boron fertilization on productivity of silage maize genotypes and NPK and B contents of the plant Journal of food Agriculture and environment vol 20 (3\&4):501-505

35. Soad.S.E.,Fatima.A.E.,Eman.M.S., and.Hassan.A.E.(2012) Effect of elevated boron concentrations on the growth and yield of barley(Hordeum Villgare L.) and alleviation of its toxicity using different plant growth modulators.Australian Journal of Crop Science 6(12):1687-1695

36. Thembakezi.K.G., Michael.T.M., Paul. K.W., and Tajudeen.O. (2015) Effect of different concentration of NPK Fertilizer on Growth and development of wild okro (Chocborusolitorius) Agric Bio Journal.N.AM., 6(31:74-30)

37. Umeri.C., Moses.H and Onyemekonwu.R,C (2016) Effects of Nitrogen and Phosphorus on the growth Performance of Maize (Zea may) in Selected Soils of Delta State,Nigeria. Advances in Crop Science and Technol;ogy 4:1 2329-8863

38. Wasonga.C.J.,Sigunga.D.O., and Musandu.A.O (2008) Phosphorous requirement by maize varieties in different soils type oef western Kenya.African crop Science JournalI vol.16.2 pp 
